\title{
Explaining Effective HRM Implementation: A Middle versus First-line Management Perspective
}

\author{
Sophie Op de Beeck ${ }^{\mathrm{a}}$, Jan Wynen ${ }^{\mathrm{a}, \mathrm{b}}$ \& Annie Hondeghem \\ ${ }^{a}$ KU Leuven, Faculty of Social Sciences, Public Governance Institute \\ ${ }^{b}$ University of Antwerp, Department of Political Science, Research Group Public \\ Administration \& Management
}

\section{Corresponding author:}

Sophie Op de Beeck

KU Leuven Public Governance Institute

Parkstraat 45 bus 3609, 3000 Leuven, Belgium

Telephone: +3216323270

E-mail: Sophie.OpdeBeeck@ soc.kuleuven.be

Key words:

line management, HRM implementation effectiveness, middle managers, first-line managers, HR devolution, strategic HRM 


\section{Biographical statements}

Sophie Op de Beeck is a senior researcher at the KU Leuven Public Governance Institute. She holds a PhD in Social Sciences (KU Leuven). Her research interests are situated in the area of personnel management in the public sector, more specifically competency management, diversity, and strategic HRM.

Jan Wynen is a post-doctoral researcher funded by FWO at both the KU Leuven Public Governance Institute and the Research Group on Public Administration \& Management of the University of Antwerp, Belgium. He holds a PhD in Social Sciences (KU Leuven). His main research interests are econometrics and public sector management.

Annie Hondeghem is professor and director of the KU Leuven Public Governance Institute, Belgium. She is also an assigned professor at the Aalborg University, Faculty of Social Science. Annie Hondeghem is a specialist in the domain of public personnel management, policy on equal opportunities and diversity, and change management. 


\section{Explaining Effective HRM Implementation: A Middle versus First-line Management}

\section{Perspective - ABSTRACT}

In this paper, we explore one of the key underlying mechanisms that mediate the HRMperformance link, namely the (effective) HRM implementation by line managers. In particular, the purpose of our study is to compare middle and first-line managers' experiences of their HR role and the factors explaining effective HRM implementation at each managerial level. By employing survey data of two Belgian federal government organisations, we examine the effect of a number of organisational, individual and interpersonal factors on the effectiveness of line managers in HRM implementation. Results indicate that both middle and first-line managers' HRM implementation effectiveness is related to organisational support, autonomous motivation and co-worker support. For the group of first-line managers, specifically, age and local office position are important in the execution of their HR tasks. For the group of middle managers, on the other hand, personnel red tape, length of service and supervisory experience contribute to their HRM implementation effectiveness. As a result, an organisation's HR department can create the internal organisational conditions necessary to facilitate successful HRM implementation by the line. At the same time, it is worth adapting the approach according to the different managerial levels. 


\section{INTRODUCTION}

In the field of strategic HRM, several theoretical perspectives and models have been proposed in trying to understand the relation between HRM and performance. One of those perspectives in the literature has pointed towards the critical role of line managers mediating the HRM-performance relationship (e.g. Alfes et al., 2013; Harney \& Jordan, 2008; Purcell \& Hutchinson, 2007). Specifically, Wright and Nishii's (2013) process model of strategic HRM has drawn attention to the distinction between intended HRM (policies developed by decision-makers), actual HRM (implemented HR practices) and perceived HRM (employee perceptions of HR practices). The overall idea is that line managers are in charge of actually implementing the intended HR practices in order that they influence the attitudes and behaviours of employees, which in turn results in individual and organisational performance outcomes (Wright \& Nishii, 2013). In other words, through performing their HR role, line managers are crucial in translating the HR policy to the workplace. All in all, this highlights the importance of line managers' HRM implementation in explaining the overall HRMperformance link.

Despite increased (research) attention for line managers' role in HRM, the effectiveness of HRM implementation by line managers still remains to be seen (Guest \& Bos-Nehles, 2013). Where the earlier studies mainly focused on delineating line management's role in HRM implementation (e.g. Hall \& Torrington, 1998; McGovern et al., 1997), some of the more recent work looks at the effectiveness of this implementation and factors explaining successful HRM implementation by the line (e.g. Bos-Nehles et al., 2013; Gilbert, 2012). From these studies, it appears that a simple, seamless transfer of HR responsibilities from HR to the line is difficult to achieve. For that reason, several authors emphasise the need for more research on HRM implementation effectiveness (Becker \& Huselid, 2006; Guest \& BosNehles, 2013). We therefore study the conditions under which HRM implementation by line managers is likely to be effective, focusing on the impact of various organisational, individual and interpersonal factors.

In addition, we find that existing research on the HR role of line managers mainly focuses on first-line management (e.g. Hutchinson \& Purcell, 2003; Lowe, 1992), and only in some occasions middle management (e.g. Currie \& Procter, 2001). However, all line managers (first-line, middle, and to some extent also top managers) have a certain amount of HRM responsibilities (Hall \& Torrington, 1998; Stanton et al., 2010), although distinctions can likely be made dependent on different considerations at different levels of management 
(Currie \& Procter, 2001). Even though current research largely ignores the existence of (possible distinctions between) these managerial levels, the topic has sparked our interest. With this paper, we therefore contribute to the literature by focusing on the comparison between middle and first-line managers' experiences of their HR role and which factors explain effective HRM implementation at each managerial level.

By employing survey data of two Belgian federal government organisations, we examine the effect of a number of organisational, individual and interpersonal factors on the perceived effectiveness of line managers in HRM implementation. More specifically, we compare the different effect of these factors across both middle and first-line managers. This allows us to answer our main research questions: Which organisational, individual and interpersonal factors affect middle and first-line line managers' HRM implementation effectiveness? How does the influence of these factors on HRM implementation effectiveness differ across middle and first-line management?

\section{EXPLAINING EFFECTIVE HRM IMPLEMENTATION}

The implementation of HRM is regarded as an important factor in unravelling the HRMperformance link. As such, the effective implementation of HRM may eventually lead to an increase in both individual and organisational performance (Wright \& Nishii, 2013). The reference to HRM implementation was primarily adopted from Wright and Nishii's (2013) distinction between intended, actual HRM and perceived HRM (cf. supra). The authors describe HRM implementation (actual HR) as the application and translation of the HR policy and practices designed or intended by the decision-makers (intended HR) in the workplace with the ultimate goal to elicit the desired employee reactions and behaviours. This is where line managers are assigned a major responsibility, holding a vital position between the HR decision-makers and the employees (Harris et al., 2002). It is now widely acknowledged, both in academia and among practitioners, that line managers have a key and increasing role to play in the implementation of HRM, an trend that is also referred to as ' $\mathrm{HR}$ devolution'. Hence, line management's involvement in HRM may positively affect employee commitment and overall organisational performance (Hutchinson and Purcell, 2003; Thornhill \& Saunders, 1998). Many researchers believe though that line managers have failed in their HR role (McGovern et al., 1997), indicating that the mere involvement of line managers in HRM does not necessarily mean that policies are implemented effectively and 
consistently. Even well-designed HR practices may become ineffective if they are not properly implemented (Khilji \& Wang, 2006). Despite the large body of literature on line management's role in executing HR tasks, however, only little attention has been paid to (the factors explaining or constraining) the effectiveness of implementation.

Given the importance of effective HRM implementation, several factors constraining line managers' execution of HR tasks are identified in the (devolution) literature. This is where the theory on role dynamics by Kahn et al. (1964; also adapted by Gilbert, 2012) provides an interesting framework. Their model distinguishes between three sets of factors that may influence an individual's role behaviour (i.e. HR role performed by line managers): organisational, individual and interpersonal factors. As such, it states that a person's role behaviour is determined by the broader organisational conditions surrounding and defining that person's role. Furthermore, it says that a person's predispositions (individual factors) will act as conditioning variables in relation to that person's role behaviour. Finally, they account for the patterns of interaction between a person and his/her role senders and how these relationships may affect that person's role behaviour (Kahn et al., 1964).

First, several organisational factors, describing the interface between individual employees (i.e. line managers) and their organisation (Muchinsky \& Morrow, 1980), may affect the effectiveness of line management's HRM implementation. We included two organisational factors in our empirical analysis: organisational support and (personnel) red tape.

Organisational support. According to organisational support theory, an employee's behaviour is contingent on the organisational context. Also, the organisational context is an important factor in stimulating employees (or line managers) to get involved in the implementation of contemporary management practices, such as HRM (Shadur et al., 1999). A key concept in this area of research is that of perceived organisational support (POS), which refers to employees' "beliefs concerning the extent to which the organisation values their contributions and cares about their well-being" (Eisenberger et al., 1986: 504). Based on the reciprocity in the social exchange relationship, greater perceived organisational support is assumed to increase an employees' affective commitment to the organisation (Eisenberger et al., 1986) and to be positively related to different desirable individual and organisational outcomes, including performance, and job satisfaction (Allen et al., 2003; Eisenberger et al., 
1990; Luthans et al., 2008; Randall et al., 1999). As such, support for the employee from the organisation is considered a strong predictor of employee behaviour (Shore \& Wayne, 1993 in Shadur et al., 1999). Although an organisation may support their employees in a number of areas, this study focuses specifically on organisational support for line management's HRM responsibilities. In this context, organisational support generally signals the importance and commitment that is attached to line managers' execution of HR tasks by the organisation (McGovern et al., 1997; Watson et al., 2007). As a result, line managers experiencing a supportive organisation are more likely to reciprocate by demonstrating favourable attitudes and behaviours, i.e. performing their HR role effectively.

(Personnel) red tape. Line managers in government organisations are in particular subjected to administrative constraints, including red tape, that may hinder their performance. Often regarded as an effect of bureaucracy, red tape has become an important variable in public administration research (Bozeman, 1993; Feeney \& Rainey, 2010). An often adopted definition of red tape refers to "rules, regulations, and procedures that remain in force and entail a compliance burden for the organization but have no efficacy for the rules' functional object" (Bozeman, 1993: 283). In practice, it may imply excessive paperwork, inefficiency, unjustifiable delays, unnecessary rules, a high degree of formalisation and as a result leads to frustration (Bozeman, 1993). In the context of HRM, Rainey, Pandey and Bozeman (1995) find that rules and laws concerning public personnel administration are the main sources of red tape. Therefore, personnel red tape is generally considered as a distinct concept (e.g. Rainey et al., 1995). Although not limited to the public sector, empirical research has shown that (personnel) red tape is more prevalent in public organisations than in private sector organisations (e.g. Baldwin 1990; DeHart-Davis \& Pandey, 2005). Despite efforts to neutralise burdensome rules and procedures in public organisations (cf. government reform under the umbrella of New Public Management), public managers, compared to private and non-profit managers, still perceive significantly higher levels of red tape and less flexible personnel rules and regulations (Brewer \& Walker, 2013; Rainey et al., 1995; Feeney \& Rainey, 2010). Not surprisingly, researchers find that employees experiencing red tape may become dissatisfied, demotivated, and unproductive (Baldwin, 1990; DeHart-Davis \& Pandey, 2005). As such, line managers' perceptions of (personnel) red tape are believed to decline their motivation and diminish their flexibility and autonomy in performing their tasks (Baldwin, 1990). For example, line managers may experience difficulties in recruiting, motivating, and retaining employees due to legislative and procedural limitations (e.g. lack of 
control over rewards) (McConville, 2006). As a result, formal rules and regulations may sharply constrain line managers in performing their HR role, which will in turn affect their HRM implementation effectiveness.

Hypotheses:

Organisational support is expected to be positively related to line managers' HRM implementation effectiveness.

(Personnel) red tape is expected to be negatively related to line managers' HRM implementation effectiveness.

A second category of explanatory factors is based on the idea that an individual's reactions and behaviour in a role can be determined by a number of personal characteristics of the individual itself (Kahn et al., 1964), i.e. the line manager in this case. Individual factors included in our study are the line manager's HR-related competency, capacity, willingness and autonomous motivation.

HR-related competency. A successful HRM implementation requires the necessary HRrelated competencies (Bos-Nehles, 2010). Generally, line managers should have insight in their organisation's HR policy and (how to implement) the HR practices as they are intended. In addition, several supporting skills can be identified, such as managing change, motivating, communicating, interpersonal skills, team building skills, and involving employees (McGovern et al., 1997; Thornhill \& Saunders, 1998). All too often, line managers lack the expertise necessary to tackle increasingly complex HR issues. For example, Maxwell and Watson (2006) found that line management's HR competency was assessed to be inadequate by both HR professionals and line managers themselves. Also, for many (new) line managers, HR issues were never before appraised or recognised as part of their job (Napier \& Peterson, 1984). Line managers that are feeling unskilled may try to avoid their HR role due to their discomfort with it (de Jong et al., 1999). Another issue here relates to the fact that line managers are often promoted because they are the best in their profession rather than because of their having good people skills (Hutchinson \& Wood, 1995). This is especially valid in the public sector, where the closed career system is still in place (Brewer, 2005). As a result, line managers may not feel equipped to handle their new HRM responsibilities (Hutchinson \& 
Wood, 1995). Whittaker and Marchington (2003: 259) therefore emphasise that more attention should be paid to how line managers are "recruited, inducted, appraised and rewarded, and trained up in the HR aspects of their jobs". Investing in the appropriate training in people management can provide a solution to line managers feeling incompetent and also make line managers feel more confident in carrying out HR tasks (Bach, 2001; Harris et al., 2002). Also, possessing HR competencies helps line managers in coping with uncertainty regarding their HR role (e.g. role ambiguity) (Gilbert, 2012). All too often, however, formal HR training tailored to an audience of line managers is limited (Harris et al., 2002; Hope-Hailey et al., 2005). Generally, we hypothesise that a lack of HR-related competencies will have a negative effect on a line managers' overall HRM implementation effectiveness.

Motivation. The (successful) enactment of HR practices by line managers will also depend on the extent to which line managers feel adequately interested and motivated. Line managers should be willing to take on their HR tasks (Bos-Nehles, 2010). Often, however, line managers don't recognise the value of adopting HR practices (Thornhill \& Saunders, 1998) or they are reluctant to accept their 'new' HRM responsibilities (McGovern et al., 1997). In addition, and as stated above, line managers' priorities often lie in meeting operational goals, while paying little attention to people management activities (Whittaker \& Marchington, 2003). Overall, effective HRM cannot be delivered by line managers who do not take their HR role seriously or who do not reflect a belief in HRM (Watson et al., 2007; Whittaker \& Marchington, 2003). Line managers' motivation can generally be graded from controlled to autonomous on what is called the 'self-determination ${ }^{1}$ continuum' (cf. selfdetermination theory; Deci \& Ryan, 2004). Controlled motivation originates from external sources (extrinsic), where people engage in an activity to obtain a reward or avoid a negative sanction. In this case, the individual experiences an obligation to behave in a specific way. The motivation would disappear if the sanction/reward is removed because the motivation is not at all internalised (Coursey \& Vandenabeele, 2012; Guay et al., 2000). This controlled type of motivation has been negatively related to organisational outcomes and personal wellbeing (Vallerand \& Ratelle, 2004). Also other research has already pointed out that rewards, such as performance-related pay, consistently fail to deliver in the public sector, possibly because of its incompatibility with public institutional rules or other powerful motivations including people pursuing public service (Perry et al, 2009). Autonomous motivation, on the

\footnotetext{
1 "Self-determination involves a true sense of choice, a sense of feeling free in doing what one has chosen to do" (Guay et al., 2000: 176).
} 
other hand, stems from the person itself (intrinsic) and states that people engage in an activity because they find it inherently enjoyable and satisfying (Coursey \& Vandenabeele, 2012; Guay et al., 2000). This type of motivation is found to positively affect organisational and personal outcomes (Vallerand \& Ratelle, 2004). Looking into line managers' HRM responsibilities, Harris et al. (2002) found, for example, that line managers are more reluctant to get involved in HRM when those tasks are pushed onto them (controlled motivation). A study by Watson et al. (2007), on the other hand, found that line managers felt a strong personal responsibility for their employees and HR, indicating a sense of ownership of their HR role (autonomous motivation). Altogether, we would expect line managers who are autonomously motivated to be more effective in implementing their HRM responsibilities.

Capacity. Notable among the drawbacks of HR devolution is that line managers often experience a lack of time to perform HR tasks and an increase in their workload (Bach, 2001). This is because additional HRM responsibilities are not always accompanied by a reduction in other daily duties, thereby increasing an often already full workload. Also, in dealing with competing demands, long-term goals often suffer under pressure from shortterm, operational targets. As a result, line managers' short-term, operational tasks are frequently given priority over HR tasks (Napier \& Peterson, 1984; Watson et al., 2007; Whittaker \& Marchington, 2003). These different demands are also present in the broader leadership literature, which distinguishes between multiple leadership roles for (public sector) managers. As such, line managers are expected to be a steward, bureaucrat, manager, entrepreneur, professional and should at the same time take up a role as coach or leader (including HR aspects) (Van Wart et al., 2012). Altogether, line managers may easily become 'overloaded' by their HR role which may lead them to be less successful in performing that role (Bos-Nehles, 2010; Hope-Hailey et al., 2005; McConville, 2006; Renwick, 2000). Therefore, having the capacity to spend sufficient time on HR tasks will help line managers to effectively implement their HRM responsibilities. 
Hypotheses:

$H R$-related competency and capacity are expected to be positively related to line managers' HRM implementation effectiveness.

Line managers are hypothesised to achieve higher HRM implementation effectiveness if they are more autonomously motivated.

Third and finally, the interpersonal factors, suggested by Kahn et al. (1994), refer to the appreciation of interactions between the role receiver (i.e. line manager) and his/her role senders (i.e. HR professionals, supervisor, colleagues, ...). Despite formal organisational structures and highlighting the importance of organisational relationships, Krackhardt and Hanson (1993: 104) state rightfully that much of the work in organisations is facilitated by the "networks of relationships that employees form across functions and divisions to accomplish tasks" (in Power et al., 2008). As such, line managers who are able to share their experiences and frustrations with others may feel encouraged and supported in their HR role (McConville, 2006). In this paper, we examined the influence of line managers' appreciation of support from HR professionals, their supervisor, and co-workers.

Support theory and the 'norm of reciprocity' (cf. organisational support) are the main theoretical underpinnings regarding the effect of these different sources of support on line managers' HRM implementation effectiveness. Simply put, support entails some kind of exchange with the expectancy of reciprocity, i.e. people usually return the favours they receive from others (Shumaker \& Brownell, 1984; Wayne et al., 1997). As such, providing support will likely result in favourable attitudes and behaviours at the receiver's end, i.e. line managers performing their HR tasks effectively. Support is said to function as a coping mechanism, helping line managers to deal with the difficulties associated with their HR role (Cohen \& McKay, 1984; Shumaker \& Brownell, 1984; Vigoda-Gadot \& Talmud, 2010). Although prior research on the relationship between support and different (performance) outcomes have not been consistent (Luthans et al., 2008), several studies do find evidence of a direct relationship between support and outcomes such as commitment, turnover intention, and job performance (Eisenberger et al., 1990; Randall et al., 1999; Rogg et al., 2001; Vigoda-Gadot \& Talmud, 2010). Below, we briefly elaborate on the impact of HR, supervisor, and co-worker support on line managers' effective HRM implementation. 
$H R$ support. As line managers are not HR specialists, they will rely on support, encouragement and advice from HR professionals in order to effectively implement their HRM responsibilities (Perry \& Kulik, 2008). Recent studies confirm this assumption and find that HR support is positively related to effective HRM implementation (Bos-Nehles, 2010) and negatively related to HR role stressors (Gilbert et al., 2011). In general, line managers expect HR "to provide the right people, at the right time, with the right skills; to advise on problem cases and difficult issues; and to encourage long-term staff development, nurturing skills within current roles and preparing workers for future advancement" (Baldwin, 2007: 8). Nevertheless, previous studies identified a lack of support or a sense of distance between line managers and HR (Bos-Nehles et al., 2011; McGuire et al, 2011), showing that successful HR support also requires willingness of HR to help line managers and provide accurate information (Hutchinson \& Wood, 1995). Altogether, line managers rely on HR support to effectively carry out their HRM responsibilities (Perry \& Kulik, 2008; Renwick, 2003).

Supervisor support. Line managers' own supervisors are considered as another source of support. In line with the definition of organisational support, Eisenberger et al. (2002) define perceived supervisor support as the degree to which employees form impressions that their superiors care about their well-being, value their contributions, and are generally supportive. Also leader-member exchange theory suggests that an interpersonal relationship evolves between employees and their supervisors (Wayne et al., 1997). A supportive supervisor may motivate line managers and, hence, increase their work performance. More specifically, their own supervisor may not only motivate line managers, but also controls and manages the immediate resources available to line mangers (Bhanthumnavin, 2003). Furthermore, line managers' own supervisor can provide information on the expectations regarding their (HR) role (Lankau et al., 2006), which may in turn result in positive outcomes. For example, Wayne et al. (1997) concluded that supportive treatment by supervisors was in earlier research found to be positively related to subordinates' affective commitment, job attitudes, and performance.

Co-worker support. Finally, the literature suggests that co-workers can be an important source of support. Zhou and George (2001: 685) define co-worker support as "co-workers assisting an employee with his/her tasks when needed by sharing knowledge and expertise or providing encouragement and support". Social comparison theory, for example, teaches us that interaction with co-workers may be helpful to an individual's work as they are exposed to the same work environment and often execute similar tasks (Cohen \& McKay, 1984; 
Joiner, 2007; Zhou \& George, 2001). As such, co-workers at the same hierarchical level may motivate line managers through sharing their personal experiences and providing overall support. Consequently, being able to rely on a supportive relationship with co-workers is generally believed to contribute to an individual's job performance (Paarlberg et al., 2008; Perry \& Porter, 1982). In other words, line managers who perceive their co-workers to be supportive, may perform better in executing their HRM responsibilities.

Hypothesis:

$H R$, supervisor and co-worker support are expected to be positively related to line managers' HRM implementation effectiveness.

\section{MIDDLE VERSUS FIRST-LINE MANAGEMENT}

Several levels of line management typically exist within an organisation. Generally, three managerial levels can be distinguished: top, middle and first-line management. Each of these is considered to have an HR role (Hall \& Torrington, 1998). With a few exceptions (e.g. Currie \& Procter, 2001; McConville, 2006), however, research on HR devolution has mainly been focused on first-line management (e.g. Purcell \& Hutchinson, 2007; Lowe, 1992). We believe, though, that distinctions are likely to exist dependent on different considerations at different levels of management (Currie \& Procter, 2001). As such, each managerial level will also have its own peculiarities regarding the HRM implementation issue. The line managers we want to concentrate on in this paper are middle and first-line managers.

First-line managers (or front-line managers, or supervisors) are at the lowest level in the organisation's management team and are mostly involved in operational tasks, controlling the daily work practices on the shop floor. They supervise the work of operating employees and report to middle management (Bos-Nehles, 2010; McConville, 2006). Hales (2005: 473) defines a first-line manager as a manager "to whom non-managerial employees report". The group of middle managers are considered more difficult to distinguish, as the boundaries between levels of hierarchy are often blurred. Simply put, middle managers are often considered 'the piggy's in the middle' positioned below top management and responsible for supervising other managers (McConville, 2006). According to Floyd and Woolridge (1997: 466 in Currie \& Procter, 2001), they "mediate, negotiate and interpret connections between 
the organisation's institutional (strategic) and technical (operational) levels". They are also responsible for finding the best way to organise human and other resources in order to achieve the objectives of their particular department or unit (Bos-Nehles, 2010). Finally, "middle managers are removed from the work floor and are accountable for a range of outcomes beyond detailed work elements" (McConville, 2006: 639). Given the difference in their position, the HR role of middle and first-line managers is also expected to take different forms (Bos-Nehles, 2010).

After stating our interest in both middle and first-line managers and delineating each group, we now look for possible differences between both managerial groups and in how they may experience their HRM responsibilities. Compared to middle managers, for example, first-line managers feel more constrained overall (Brewer \& Walker, 2013). While mediating between higher-level managers and front-line employees, first-line managers are considered the most important leadership asset sheer numbers and direct impact. In this sense, the importance of the group of first-line managers lies in their direct influence on employees' attitudes and motivations toward their work (Brewer, 2005; McConville, 2006). Middle managers, on the other hand, have their own peculiarities. They are closer to the top, and hence, closer to individual HR professionals/managers. Middle managers are also involved in the development as well as the implementation of HRM (Currie \& Procter, 2001). As a result, middle managers may have more insight into the rationale behind and the intent of the HR practices they are implementing. In addition, middle managers' "middleness" creates conflicts in objectives as middle managers are caught between the directives from their seniors, and the demands and problems from their subordinates (line managers) below (Hallier \& James, 1997; McConville, 2006). Furthermore, middle managers are expected to be a role model for first-line managers, demonstrating their commitment to HRM (Jackson \& Humble, 1994; Purcell \& Hutchinson, 2007). Besides the regular conflicts inherent to a managerial position (cf. supra: multiple leadership roles), middle managers may therefore face additional stress being pulled into different directions. At the same time, middle managers are expected to control, coordinate and balance the various tensions and demands (McConville, 2006).

In relation to our topic of HR devolution, some researchers have studied the reactions of various managerial levels to their HRM responsibilities. For example, Watson et al. (2007) found that strategic managers are more involved in HRM than first-line managers. Also BosNehles (2010) says that higher-level managers are probably in a better position to recognise 
and execute their HRM responsibilities, while lower-level managers still need to explore (the boundaries of) their HR role. The author also finds that higher-level managers have more desire (or willingness) and greater capacity to perform their HRM responsibilities (BosNehles, 2010).

From the previous paragraphs, it seems meaningful to distinguish between middle and first-line managers. The differences inherent to their respective position will likely manifest themselves in different approaches towards their HRM responsibilities. Hence, we may also expect differences in the way both groups perform their HR role (effectiveness of HRM implementation) and the contextual factors that may influence their HR role (e.g. motivation, capacity).

Altogether, we formulated three main hypotheses based on which data analyses and results are structured.

H1: Both middle and first-line managers' HRM implementation effectiveness is significantly related to several organisational, individual, and interpersonal factors (more detailed hypotheses are presented in the section above).

H2: Middle and first-line managers are expected to have different perceptions of (some of) the explanatory factors.

H3: The relationship between the explanatory factors and line managers' HRM implementation effectiveness is affected by the middle versus first-line manager position.

\section{RESEARCH DESIGN}

\section{Data}

Our analyses are based on data gathered in June 2013 through an online survey in two organisations within the Belgian federal government. These purposely selected organisations differ on some key elements to this topic, including the degree of HR devolution as well as their maturity regarding leadership development. Both are, however, large organisations (>1000 employees) with a geographically decentralised structure and mostly subjected to the same legislative framework regarding personnel issues, which increases their comparability 
(most-similar, comparable case study design with variation on key elements). Our population is made up of middle managers (MM) and first-line managers (FLM) in both organisations. After data cleaning, our data set contained 1,222 observations in total, of which 372 middle managers and 850 first-line managers (response rate: 34\%; sample representative for the examined organisations). We distinguished between middle and first-line managers based on the question whether a manager leads a group of managerial employees (supervisors). A positive response to this question, implies a middle manager position, while a negative answer implies a first-line manager position.

\section{Measures}

The variables included in our analyses were mainly based on existing measurement instruments as well as adapted operationalisations. Below, we describe the measures for the dependent, independent and control variables. A detailed overview table with the concepts, operationalisations and survey questions/items used to measure the variables can be found in appendix.

Dependent variable. For the dependent variable, i.e. line managers' HRM implementation effectiveness, we rely on a self-reported (HR role) performance measure. More specifically, we used a four-item scale that was previously used by Vandenabeele (2009) and attuned it to the context of our research. A sample item is: "I think I am performing well in executing my HRM responsibilities". Such self-rated measures are regularly used within public administration (e.g. Bright, 2007) and HRM research (e.g. Rodwel et al., 1998). Nevertheless, we acknowledge that confirmation by more formal, independent and 'objective' ratings of performance might have been preferable, but these were unfortunately not available. Given the self-reported performance measure, we will refer to 'line managers' perceived effectiveness of HRM implementation' in the remainder of this paper. The 'HRM responsibilities' or 'HR tasks' referred to in the survey items relate to a list of 26 HR tasks (originally constructed by Gilbert (2012)) that was part of another question in the survey. The list includes tasks such as determining future personnel needs, providing feedback on the work and performance to employees, and monitoring and redirecting the career of employees. In other words, we asked line managers to assess their own performance of effectiveness in implementing HRM for their team, keeping that list of HR tasks in mind. 
Independent variables. Note that self-reported, perceptual measures were also used for all independent variables. All organisational, individual and interpersonal variables are based on middle and first-line managers' perceptions and experiences.

To measure organisational support, we used a four-item scale developed by Zhou and George (2001) and adjusted it to our research topic. A sample item is: "The execution of HR tasks by line managers is encouraged in my organisation".

The measures for both red tape and personnel red tape were based on Rainey et al. (1995). The general scale of red tape was measured using the following question: "If red tape is defined as 'burdensome administrative rules and procedures that have negative effects on the organisation's effectiveness', how would you assess the level of red tape in your organisation?" Respondents were asked to indicate the appropriate response between 0 and 10, with 0 indicating 'almost no red tape' and 10 indicating 'great deal of red tape'. Personnel red tape was measured by means of a five-item scale indicating the effect of formal personnel rules on people management practices. An example item is: "Even if an employee is a poor performer, formal rules make it hard to remove him or her from the organisation".

Line management's HR-related competency was initially measured using a six-item scale, based on the occupational self-efficacy scale of Schyns and von Collani (2002). A sample item is: "I am sufficiently trained to execute my HR tasks".

To measure line management's capacity, we used four items that were adapted from the role overload scale of Reilly (1982). Capacity problems often manifest themselves in a role overload, where line managers lack sufficient time to execute their HR tasks. A sample item is: "I feel I have to perform HR tasks hastily and maybe less carefully in order to get everything done" (reversed scoring).

Autonomous motivation was measured using eight items representing the controlledautonomous motivation continuum. Although adapted to our research context, this scale is originally based upon the Academic Self-regulation Questionnaire (Grolnick \& Ryan, 1989; previously used by Vandenabeele (2008) and Coursey \& Vandenabeele (2012)). The relative autonomy index is further calculated as an additive weighted score based on the eight items, in which external, introjected, identified, and intrinsic regulation (cf. continuum controlledautonomous motivation) are each measured by 2 items. In calculating the index, external regulation was weighted -2 , introjection -1 , identification 1 and intrinsic motivation 2 . Therefore, the additive scale presenting the relative autonomy index (or the extent of 
autonomous motivation) ranges in this case from -12 to 12 . A sample item, representing identification, is: "I try to do my best in executing my HR tasks, because I consider it my duty".

HR support, supervisor support, and co-worker support were all measured using the same five-item scale, adjusted to the support provider in question. This measure was developed by Gilbert et al. (2011) based on support scales by Perry and Kulik (2008) and House (1981). A sample item is: "If necessary, I can count on the expertise of the HR department/my supervisor/my co-workers to execute my HR tasks".

Control variables. To control for individual differences, the line managers' gender, age (and age squared), length of service in the organisation, supervisory experience, span of control, central versus local office position, and organisation were taken into account.

All items on our dependent and independent variables (except for red tape, cf. supra) were formulated on a five-point Likert scale, ranging from one (entirely disagree) to five (entirely agree). As our key variables were measured using a multiple-item scale, an index was calculated averaging the relevant items (with the exception of 'autonomous motivation', cf. supra) based on exploratory factor analysis using a polychoric correlation matrix ${ }^{2}$. Based on the EFA analysis, a number of changes were made. The most noticeable result is that items from our performance (perceived implementation effectiveness) and competency measures are being combined in a single factor. This may be explained by the fact that we make use of a self-rated performance measure, where we ask line managers how they are doing in performing their HRM responsibilities. At the same time, we ask them whether they find themselves suitable, skilled and competent to execute their HR tasks. Instinctively, these issues are closely related, as is thus also apparent from the EFA results. To resolve this problem, we have chosen to remove HR-related competency as an independent variable and also drop the competency-related items from the measure for perceived HRM implementation effectiveness. Consequently, the measure for line managers' perceived HRM implementation effectiveness only includes the performance-items. In addition, one of the performance items

\footnotetext{
${ }^{2}$ Holgado-Tello et al. (2010: 165) have shown that "when construct validity is analysed according to ordinal data obtained from Likert scales, the factor results show a better fit to the theoretical model when the factorisation is carried out using the polychoric rather than the Pearson correlation matrix. (...) At all events, the factor results obtained (from both an exploratory and confirmatory point of view) when we use polychoric correlations reproduce better the measurement model present in the data, regardless of the number of factors." The results of the exploratory factor analysis are available upon request.
} 
and one of the capacity items were dropped after factor analysis (factor loadings under 0.5). The final measure for line managers' perceived HRM implementation effectiveness is made up of three items (cf. table in appendix). The reliability of the final scales is demonstrated by Cronbach's alphas all ranging between 0.73 and 0.94 . Finally, the correlation analysis among our variables showed nothing out of the ordinary. Not surprisingly, the highest correlation is found between age, age squared, length of service and years of supervisory experience (cf. correlation matrix in appendix). Leaving out 'age squared', the test for multicollinearity, using the variance inflation factor, however, showed a mean VIF equalling 1.42 whereby, as expected, the highest VIFs exists for age (2.32), length of service (1.87) and supervisory experience (1.87). These values indicate that no collinearity exists between the variables.

\section{ANALYSES AND RESULTS}

In general, the results (partly) confirm our three main hypotheses. First, we find significant differences between middle and first-line managers in how they perceive several variables included in our analyses (H2). From table 1, presenting the descriptive statistics, we can derive that a significant perceptual difference is found between middle and first-line managers on the dependent variable, two of the independent variables and almost all control variables. Middle managers' perceived HRM implementation effectiveness is significantly higher than that of first-line managers. Furthermore, middle managers are more autonomously motivated and rate HR support higher than their first-line colleagues. Regarding the control variables, middle managers are on average older than first-line managers, they have a longer length of service and a greater supervisory experience. Also, the span of control is larger among middle managers. Finally, we can see that there are fewer women in the group of middle managers (26\%), compared to the first-line managers (40\%). Although this may be an indication of women experiencing difficulties to entering the higher ranks of the organisation, a phenomenon labelled as the 'glass ceiling' (Powell \& Butterfield, 1994), these figures are not that bad. For example, the overall figure of $36 \%$ is in line with the target of $33 \%$ women in management positions set in the federal government (Bossens et al., 2013). While there is still work to be done in the higher echelons of management, women do appear to occupy an increasing percentage of management positions (Wynen et al., 2015). 
We employed a linear regression model (OLS) with robust standard errors to analyse both middle and first-line managers' perceived HRM implementation effectiveness and how it can be explained by several organisational, individual and interpersonal factors ${ }^{3}$. Given our interest in the middle versus first-line difference and the fact that both groups differ significantly on the dependent variable, we completed the remainder of our analyses for each group separately. From these analyses, we found evidence for perceived HRM implementation effectiveness to be significantly related to factors at organisational, individual, and interpersonal level (H1). However, not all expected effects were confirmed. Additionally, different explanatory effects are found for middle versus first-line managers (H3). The full results are presented in table 2 and discussed further below.

\section{Please include Table 2 here (OLS regression results)}

First-line managers' (hereafter FLM) perceived HRM implementation effectiveness (column A in table 2) is positively related to organisational support, autonomous motivation, co-worker support, age and local office position. A negative relationship exists between FLMs' perceived HRM implementation effectiveness and age squared. In other words, the higher a first-line manager's perception of organisational or co-worker support, the higher his/her perceived HRM implementation effectiveness. Also, a first-line manager reports his/her HRM implementation to be more effective when he/she is more autonomously motivated. In addition, FLMs who are employed in a local office (geographically decentralised unit) perceive higher HRM implementation effectiveness. Regarding age, we observe two things: (1) FLMs say to perform better as they get older, and (2) the square age term indicates a concave (inverted U-shaped) relationship. Although the perceived effectiveness of HRM implementation increases as FLMs get older, it starts to decrease from a certain point. As depicted in Figure 1, we see an increase in perceived HRM implementation effectiveness until the age of 45.5, after which it decreases.

\footnotetext{
${ }^{3}$ Since the dependent is bounded between 1 and 5, we also did a robustness check using the Tobit model. However, the Tobit results didn't significantly differ from the regular OLS results. As Tobit results are more difficult to interpret (marginal effects), we decided to only report the OLS results. Tobit results are available upon request.
} 
Middle managers' (hereafter MM) perceived HRM implementation effectiveness (column B in table 2) is positively impacted by organisational support, autonomous motivation, co-worker support and length of service. A negative effect is found for personnel red tape. Just like the FLMs, the MMs' perceived HRM implementation effectiveness is thus higher when they feel supported by the organisation and their co-workers. Also, MMs who feel more autonomously motivated will perceive their HRM implementation to be more effective. Personnel red tape, on the other hand, is confirmed to have a damaging effect on MMs' reported HRM implementation effectiveness. Finally, MMs perceive themselves to be more effective in their HR role as they have more seniority (length of service) in their organisation.

Based on the regression results, we already found different outcomes for the middle versus the first-line managers. In other words, the determinants of perceived HRM implementation effectiveness differ between the two groups. Both MMs' and FLMs' perceived HRM implementation effectiveness is related to organisational support, autonomous motivation and co-worker support. However, where age (and age squared) and local office position are important towards FLMs' perceived effective implementation, they are not found significant to the group of MMs. On the other hand, personnel red tape and length of service are only important in relation to MMs' perceived HRM implementation effectiveness. In addition to these findings, we did further tests indicating any significant differences between MMs and FLMs in the effects of various independent variables on the dependent. As to be expected, we found significant differences between the two groups of managers regarding the effect of personnel red tape, age (and age squared), length of service, and local office position. These variables are the ones that are only significant for one of the two management groups. Interestingly though, we also found a significant difference between MMs and FLMs with regards to the effect of autonomous motivation on their perceived HRM implementation effectiveness. Although autonomous motivation is significant for both management groups, the effect is significantly higher in case of MMs compared to FLMs. 


\section{DISCUSSION AND CONCLUSION}

In recent years, the topic of effective HRM implementation by line managers has gained ground in strategic HRM literature (Chow, 2012; Guest \& Bos-Nehles, 2013). Involving line managers in HRM is, however, not at all straightforward. Therefore, the purpose of this paper was to examine the conditions under which HRM implementation by line managers is likely to be effective, focusing on the impact of various organisational, individual and interpersonal factors. More specifically, we compare middle and first-line managers' experiences of their HR role and the factors related to perceived HRM implementation effectiveness at each managerial level.

\section{Discussion}

Overall, our results are in line with our expectations from the literature and show that middle and first-line managers have different experiences regarding their HR role and the conditions fostering their perceived HRM implementation effectiveness. In general, some key defining elements distinguishing middle from first-line managers were apparent from our results. For example, middle managers are on average older than first-line managers, they have a longer length of service, a greater supervisory experience, and a larger span of control. Moreover, our results contained evidence of the so-called 'glass ceiling', as women were less represented in the group of middle managers compared to the group of first-line managers. Apart from these 'basic' differences, we also established a difference in perceived HRM implementation effectiveness between middle and first-line managers. Middle managers report significantly higher effectiveness than first-line managers, possibly due to the former group having more experience in their HR role, and hence, more confidence in their performance. This outcome is also in line with the literature, which finds higher-level managers to be more involved in HRM and better able to recognise and execute their HRM responsibilities (Bos-Nehles, 2010; Watson et al., 2007). Furthermore, middle managers perceive HR support to be higher than their first-line colleagues, possibly because middle managers are closer to the top, and hence, closer to HR professionals in the organisation (Currie \& Procter, 2001). Finally, middle managers are more autonomously motivated than first-line managers. Again, this may be linked to their enhanced HR role experience. Also, their proximity to HR professionals may imply that middle managers have more insight into 
the intended HR policy and the rationale behind their HR tasks, which may spike their interest in HRM.

The main part of our findings, however, relates to the conditions underlying effective HRM implementation. As such, we found significant effects for organisational support, autonomous motivation, and co-worker support among both middle and first-line mangers. One of the larger effect sizes is found for co-worker support, a factor that, up until now, has hardly been studied empirically in relation to HR devolution (except e.g. in one of our previous papers, Op de Beeck et al., 2013). Line managers, both middle and first-line, are clearly finding support for their HR role through sharing expertise and experiences with their co-workers, as suggested by support theory (Joiner, 2007; Zhou and George, 2001). As a result, the encouragement of their peers contributes to their perceived HRM implementation effectiveness. Not only co-workers, but also the organisation in general may provide support through signalling the importance attached to line managers' execution of HR tasks. In line with the literature, line managers experiencing a supportive organisation are more likely to perform their HR role effectively (McGovern et al., 1997; Shore \& Wayne, 1993 in Shadur et al., 1999). Next, the perceived HRM implementation effectiveness also depends on the extent to which line managers are autonomously motivated in executing their HR tasks, confirming the results from previous studies (Bos-Nehles, 2010; Vallerand \& Ratelle, 2004; Watson et al., 2007). In other words, line managers who show a genuine interest in and a sense of ownership of their HRM responsibilities are likely to find themselves to be more successful in HRM implementation. Forcing their HR role upon them by obligation, reward, or sanction (controlled motivation) will therefore fail to deliver.

For the group of first-line managers, specifically, age and local office position contribute significantly to the execution of their HR tasks. As such, the perceived HRM implementation effectiveness of first-line managers increases as they get older. From the age of 45.5, however, we see a decrease in their HR role performance. An explanation may lie in the fact that leadership development has only recently been introduced in the organisations studied here (e.g. organisation 1 started in 2009 versus 2011/2013 in organisation 2). More specifically, the 'younger generation' of first-line managers has been confronted with this issue at the early stages of their supervisory career, whereas the 'older' first-line managers have hardly ever been assessed on their people skills. One could maybe carefully mention the term 'generation effect' here. Also, first-line managers who are employed in a local office (geographically decentralised unit) indicate higher HRM implementation effectiveness. 
Although this finding is instinctively contradictory, it may be explained by first-line managers possibly experiencing greater freedom in decision-making when employed in a local office. Or maybe the organisation's strategy is to move the best first-line managers to the local offices.

For the group of middle managers, on the other hand, personnel red tape and length of service are of importance to their perceived HRM implementation effectiveness. In line with the literature (Baldwin, 1990; McConville, 2006), personnel red tape constrains middle managers in performing their HR role. The fact that this is only significant for middle managers may be explained by their overall 'middleness', which makes them susceptible to rules and regulations both at strategic and operational level. Being accountable to both their seniors and their subordinates (first-line managers) (Hallier \& James, 1997; McConville, 2006), middle managers may feel, even more so than others in the organisation, obliged to adhere to the many burdensome rules. Finally, middle managers' perceived HRM implementation effectiveness increases as they have more seniority (length of service) in their organisation. Likely, middle managers will have built up experience in people management and will have invested in their career the longer they are employed within the same organisation (Moynihan \& Landuyt, 2008), possibly resulting in them performing better in their HR role.

Generally, there's not one particular category of explanatory factors that stands out to be important in predicting line managers' perceived HRM implementation effectiveness. At the organisational level, organisational support plays an important part, and also personnel red tape is significant in case of the group of middle managers. At the individual level, line managers' autonomous motivation is related to their perceived HRM implementation effectiveness. At interpersonal level, the co-workers are key in providing support towards line managers' perceived HRM implementation effectiveness. In addition, we didn't detect any differences between both organisations included in our study. Although both organisations are at different stages of maturity regarding HR devolution and leadership development, this didn't show in the results. Probably, any organisational difference is incorporated in the other explanatory factors. From a previous study, for example, differences between organisations were no longer significant when the interpersonal (support) variables were introduced to the equation. In other words, organisational differences were represented in different appreciations of support. Possibly, this is what also happened here. 


\section{Practical implications}

Overall, our results show that it is important to account for and possibly create the internal organisational conditions that facilitate successful HRM implementation by the line. In this regard, the HR department and the organisation in general can take action in several domains.

First, it is worth to reflect on the distinction between middle and first-line managers. Our results indicated several differences between both managerial groups regarding the HR devolution issue. For example, both middle and first-line managers clearly have a role in implementing HRM, but may differ in the way they execute their HR tasks. Also, the conditions fostering perceived effective HRM implementation are somewhat different between middle and first-line managers. It is, however, not required to align both groups' ideas and perceptions. On the contrary, attention should be paid to identifying the different needs and wishes of each group. Afterwards, HR's approach towards facilitating HRM implementation by the line should be adapted according to the different managerial levels.

Second, our results point to the importance of the right type of motivation for line managers to engage in HRM. More specifically, HRM implementation will benefit from line managers, both middle and first-line, to be autonomously motivated when it comes to their HR tasks. The HR department should therefore foster this type of motivation. Instead of enforcing line managers' HR role in a controlled manner (obligate/reward/sanction), it is worth investigating ways to make it 'enjoyable' and 'satisfying' for line managers to take on their HR tasks. This will, however, be a difficult exercise as it likely requires a change in the line managers' mindset towards HRM.

Third, it may be worthwhile to invest in networking activities specifically focusing on line managers' role as people managers (including HRM implementation). From our results, it appears that support from the organisation and from co-workers is essential to achieve effective HRM implementation. Regular networking activities are therefore interesting in order to encourage interaction with co-workers and to signal the organisation's commitment regarding line managers' HR role.

Finally, there is the significance of personnel red tape for middle managers and local office position for first-line managers. Both factors are difficult to remedy, if that is at all what one would want. Personnel red tape is generally inherent to public sector organisations and cannot be easily eliminated. Although middle managers may feel constrained in their HR 
role because of burdensome rules, it may be more useful to identify and highlight those areas in which middle managers do have the necessary room for manoeuvre. Also regarding firstline managers' local office position, it should first be examined what are the underlying reasons for those in the local office to indicate higher HRM implementation effectiveness than those employed in the central office.

\section{Limitations}

In interpreting the results of our study, it is important to take into account the following limitations. First, it is a cross-sectional study. Although our hypotheses are based on sound theoretical arguments, we cannot make causal inferences from our results. Hence, we also cannot rule out the possibility of reverse causality. Future research may therefore collect longitudinal data to assess the direction of these relationships. Second, as mentioned earlier, using a self-reported performance measure may lead to biased results. The problem encountered with the measure for HR-related competency demonstrates the imperfection of the performance measure. Probably, a more accurate measure of line managers' HR role performance would be to ask subordinates to assess the way their line managers execute HR practices on the work floor. In addition, common method bias may occur in our results as all data in our study are self-reported and were simultaneously collected. Third, limiting our study to only two organisations leaves us with little possibilities of generalising our results. However, as they are two government organisations, some tentative conclusions may be made in the context of the Belgian federal government. Future research may therefore extend the research to multiple organisations, also outside the (federal) government context. Finally, an in depth qualitative research approach may provide more detailed information on the actual experiences and feelings of both middle and first-line managers towards their HRM responsibilities.

\section{REFERENCES}

Alfes, K., Truss, C., Soane, E.C., Rees, C. \& Gatenby, M. (2013). The relationship between line manager behavior, perceived HRM practices, and individual performance: Examining the mediating role of engagement. Human Resource Management. 52(6): 839859. 
Allen, D.G., Shore, L.M. \& Griffeth, R.W. (2013). The Role of Perceived Organisational Support and Supportive Human Resource Practices in the Turnover Process. Journal of Management. 29(1): 99-118.

Bach, S. (2001) HR and new approaches to public sector management: Improving HRM capacity. World Health Organisation. Workshop on Global Health Workforce Strategy. France: Annecy. 9-12 December 2000.

Baldwin, J.N. (1990) Perceptions of Public versus Private Sector Personnel and Informal Red Tape: Their Impact on Motivation. The American Review of Public Administration. 20 (7): 7-28.

Baldwin, S. (2007) Customer Views of the HR Function: a literature review. Brighton: Institute for Employment Studies.

Becker, B.E. \& Huselid, M.A. (2006). Strategic human resource management: Where do we go from here? Journal of Management. 32: 898-925.

Bhanthumnavin, D. (2003). Perceived Social Support from Supervisor and Group Members' Psychological and Situational Characteristics as Predictors of Subordinate Performance in Thai Work Units. Human Resource Development Quarterly. 14(1): 79-97.

Bos-Nehles, A. (2010) The line makes the difference: Line managers as effective HR partners. [doctoral thesis] Universiteit Twente.

Bos-Nehles, A., Van Riemsdijk, M.J. \& Looise, J.K. (2013). Employee perceptions of line management performance: Applying the AMO theory to explain the effectiveness of line managers’ HRM implementation. Human Resource Management. 52(6): 861-877.

Bossens, N., Cautaert, E., Demuzere, S., Op de Beeck, S. (2013). Kwantitatieve en kwalitatieve benchmarking van het interne gelijke kansen- en diversiteitsbeleid van de Vlaamse overheid. [external report] Leuven: Instituut voor de Overheid. 185 pp.

Bozeman, B. (1993). A Theory of Government "Red Tape". Journal of Public Administration Research and Theory. 3 (3): 273-303.

Brewer, G.A. (2005). In the Eye of the Storm: Frontline Supervisors and Federal Agency Performance. Journal of Public Administration Research and Theory. 15: 505-527. 
Brewer, G.A. \& Walker, R.M. (2013). Personnel Constraints in Public Organizations: The Impact of Reward and Punishment on Organizational Performance. Public Administration Review. 73 (1): 121-131.

Bright, L. (2007). Does Person-Organization Fit Mediate the Relationship between Public Service Motivation and the Job Performance of Public Employees? Review of Public Personnel Administration. 27(4): 361-379

Chow, I. H.-S. (2012). The roles of implementation and organizational culture in the HR-performance link. The International Journal of Human Resource Management. 23(15): 3114-3132.

Cohen, S. \& McKay, G. (1984). Social Support, Stress and the Buffering Hypothesis: A Theoretical Analysis. In Baum, A., Taylor, S.E. \& Singer, I.E. (Eds.). Handbook of Psychology and Health. Hillsdale, NJ.

Coursey, D. \& Vandenabeele, W. (2012). Empirical validation of the relative autonomy index - a self-determination perspective on work motivation in the public sector. Paper presented at the XVI Annual Conference of the International Research Society for Public Management (IRSPM). Rome, Italy. 11-13 April 2012.

Currie, G. \& Procter, S. (2001) Exploring the relationship between HR and middle managers. Human Resource Management Journal. 11 (3): 53-69.

Deci, E.L. \& Ryan, R.M. (2004). Handbook of self-determination research. Suffolk: The University of Rochester Press.

DeHart-Davis, L. \& Pandey, S.K. (2005). Red Tape and Public Employees: Does Perceived Rule Dysfunction Alienate Managers? Journal of Public Administration Research and Theory. 15(1): 133-148.

de Jong, J.A., Leenders, F.J. \& Thijssen, J.G.L. (1999). HRD tasks of first-level managers. Journal of Workplace Learning. 11(5): 176-183.

Eisenberger, R., Fasolo, P. \& Davis-LaMastro, V. (1990). Perceived organizational support and employee diligence, commitment, and innovation. Journal of Applied Psychology. 75: 51-59.

Eisenberger, R., Huntington, R., Hutchison, S. \& Sowa, D. (1986). Perceived organizational support. Journal of Applied Psychology. 71: 500-507. 
Eisenberger, R., Stinglhamber, F., Vandenberghe, C., Sucharski, I.L., \& Rhoades, L. (2002). Perceived Supervisor Support: Contributions to Perceived Organizational Support and Employee Retention. Journal of Applied Psychology. 87(3): 565-573.

Feeney, M.K. \& Rainey, H.G. (2010). Personnel Flexibility and Red Tape in Public and Nonprofit Organizations: Distinctions Due to Institutional and Political Accountability. Journal of Public Administration Research and Theory. 20(4): 801-826.

Gilbert, C. (2012). HRM on the line: Empirical studies on the prerequisites and importance of effective HRM implementation. [doctoral thesis] Faculteit Economie en Bedrijfswetenschappen, KU Leuven.

Gilbert, C., De Winne, S. \& Sels, L. (2011). Antecedents of front-line managers' perceptions of HR role stressors. Personnel Review. 40(5): 549-569.

Guay, F., Vallerand, R.J. \& Blanchard, C. (2000). On the Assessment of Situational Intrinsic and Extrinsic Motivation: The Situational Motivation Scale (SIMS). Motivation and Emotion. 24(3): 175-213.

Guest, D. \& Bos-Nehles, A. (2013). HRM and Performance: The Role of Effective Implementation. In: Guest, D.E., Paauwe, J. \& Wright, P. (eds.). HRM and performance: Achievements and challenges. Chichester, UK: John Wiley \& Sons Ltd. pp. 79-96.

Hales, C. (2005). Moving down the line? The shifting boundary between middle and first-line management. Journal of General Management. 32(2): 31-55.

Hall, L. \& Torrington, D. (1998) Letting go or holding on - The devolution of operational personnel activities. Human Resource Management Journal. 8 (1): 41-55.

Hallier, J. \& James, P. (1997). Middle Managers and the Employee Psychological Contract: Agency, Protection and Advancement. Journal of Management Studies. 34 (5): 703-728.

Harney, B. \& Jordan, C. (2008). Unlocking the black box: line managers and HRMPerformance in a call centre context. International Journal of Productivity and Performance Management. 57(4): 275-296.

Harris, L., Doughty, D. \& Kirk, S. (2002) The devolution of HR responsibilities Perspectives from the UK's public sector. Journal of European Industrial Training. 26(5): 218-229. 
Holgado-Tello, F.P., Chacón-Moscoso, S., Barbero-García, I. \& Vila-Abad, E. (2010). Polychoric versus Pearson correlations in exploratory and confirmatory factor analysis of ordinal variables. Quality \& Quantity. 44(1): 153-166.

Hope-Hailey, V., Gratton, L., McGovern, P., Stiles, P. \& Truss, C. (1997). A chameleon function? HRM in the '90s. Human Resource Management Journal. 7(3): 5-18.

House, J.S. (1981). Work Stress and Social Support. Reading, MA: Addison-Wesley.

Hutchinson, S. \& Purcell, J. (2003) Bringing policies to life: The vital role of front line managers in people management. London: Chartered Institute for Personnel and Development.

Hutchinson, S. \& Wood, S. (1995) The UK experience. In Hutchinson S. \& Brewster, C. (Eds.) Personnel and the Line: Developing the New Relationship. Wimbledon: IPM.

Jackson, D. \& Humble, J. (1994). Middle Managers: New Purpose, New Directions. Journal of Management Development. 13 (3): 15-21.

Joiner, T.A. (2007) Total quality management and performance: The role of organization support and co-worker support. International Journal of Quality \& Reliability Management. 24 (6): 617-627.

Kahn, R.L., Wolfe, D.M., Quinn, R.P., Snoek, J.D. \& Rosenthal, R.A. (1964) Organizational Stress: Studies in Role Conflict and Ambiguity. New York: John Wiley \& Sons Inc.

Khilji, S.E. \& Wang, X. (2006). 'Intended' and 'implemented' HRM: the missing linchpin in strategic human resource management research. International Journal of Human Resource Management. 17(7): 1171-1189.

Lankau, M.J., Carlson, D.S. \& Nielson, T.R. (2006). The mediating influence of role stressors in the relationship between mentoring and job attitudes. Journal of Vocational Behavior. 68(2): 308-22.

Lowe, J. (1992) 'Locating the Line': The Front-Line Supervisor and Human Resource Management. In Blyton, P. \& Turnbull, P. (Eds.) Reassessing Human Resource Management. London: Sage Publications. pp. 148-168. 
Luthans, F., Norman, S.M., Avolio, B.J. \& Avey, J.B. (2008). The mediating role of psychological capital in the supportive organizational climate - employee performance relationship. Journal of Organizational Behavior. 29: 219-238.

Maxwell, G.A. \& Watson, S. (2006) Perspectives on line managers in human resource management: Hilton International's UK hotels. International Journal of Human Resource Management. 17(6): 1152-1170.

McConville, T. (2006). Devolved HRM responsibilities, middle-managers and role dissonance. Personnel Review. 35(6): 637-653.

McGovern, P., Hope-Hailey, V. \& Stiles, P. (1997) Human resource management on the line? Human Resource Management Journal. 7 (4): 12-29.

McGuire, F., McGuire, D. \& Sanderson, M. (2011). Between A Rock And A Hard Place: An Exploration Of Line Manager Partnership Working With Trade Unions And The HR Function. University Forum for Human Resource Development. Online: http://www.ufhrd.co.uk/wordpress/mcguire-f-mcguire-d-and-sanderson-m-between-a-rockand-a-hard-place-an-exploration-of-line-manager-partnership-working-with-trade-unionsand-the-hr-function/

Moynihan, D.P. \& Landuyt, N. (2008). Explaining Turnover Intention in State Government: Examining the Roles of Gender, Life Cycle, and Loyalty. Review of Public Personnel Administration. 28(2): 120-143.

Muchinsky, P.M., \& Morrow, P.C. (1980). A multidisciplinary model of voluntary employee turnover. Journal of Vocational Behavior. 17. 263-290.

Napier, N.K. \& Peterson, R.B. (1984). Putting Human Resource Management at the Line Manager Level. Business Horizons. 27(1): 72-82.

Op de Beeck, S. \& Hondeghem, A. (2013). Explaining Effective HRM Implementation by Line managers in the Public Sector: Relying on an Organisational Support System. Paper presented at the the Annual Conference of the American Society for Public Administration (ASPA). Washington DC, USA. March 14-18, 2014.

Paarlberg, L.E., Perry, J.L. \& Hondeghem, A. (2008). From Theory to Practice: Strategies for Applying Public Service Motivation. In: Hondeghem, A. \& Perry, J.L. (Eds.) Motivation in Public Management: The Call of Public Service. Oxford: Oxford University Press. pp. 268-293. 
Perry, J.L., Engbers, T.A. \& Jun, S.Y. (2009). Back to the Future? Performance-Related Pay, Empirical Research, and the Perils of Persistence. Public Administration Review. 69(1): $39-51$.

Perry, E.L. \& Kulik, C.T. (2008) The devolution of HR to the line: Implications for perceptions of people management effectiveness. The International Journal of Human Resource Management. 19 (2): 262-273.

Perry, J.L. \& Porter, L.W. (1982). Factors affecting the context for motivation in public organizations. Academy of Management Review. 7(1): 89-98.

Powell, G.N. \& Butterfield, D.A. (1994). Investigating the "Glass Ceiling" Phenomenon: An Empirical Study of Actual Promotions to Top Management. The Academy of Management Journal. 37(1): 68-86.

Power, J.R., Milner, B. \& Garavan, T. (2008). Illuminating the Relationship Between Line Managers and HR Professionsals A Social Exchange Perspective. In: IAM Conference, September 3rd - 5th, Dublin.

Purcell, J. \& Hutchinson, S. (2007). Front-line managers as agents in the HRM performance causal chain: theory, analysis and evidence. Human Resource Management Journal. 17(1): 3-20.

Rainey, H.G., Pandey, S. \& Bozeman, B. (1995) Public and Private Managers' Perceptions of Red Tape. Public Administration Review. 55 (6): 567-574.

Randall, M.L., Cropanzano, R., Bormann, C.A. \& Birjulin, A. (1999). Organizational politics and organizational support as predictors of work attitudes, job performance, and organizational citizenship behavior. Journal of Organizational Behavior. 20: 159-174.

Reilly, M.D. (1982). Working Wives and Convenience Consumption. Journal of Consumer Research. 8(4): 407-418.

Renwick, D. (2000). HR-line work relations: a review, pilot case and research agenda. Employee Relations. 22(2): 179-205.

Renwick, D. (2003) Line manager involvement in HRM: an inside view. Employee Relations. 25 (3): 262-280. 
Rodwell, J.J., Kienzle, R. \& Shadur, M.A. (1998). The relationship among work-related perceptions, employee attitudes, and employee performance: The integral role of communications. Human Resource Management. 37(3-4): 277-293.

Rogg, K.L., Schmidt, D.B., Shull, C. \& Schmitt, N. (2001). Human resource practices, organizational climate, and customer satisfaction. Journal of Management. 27: 431-449.

Schyns, B. \& von Collani, G. (2002). A new occupational self-efficacy scale and its relation to personality constructs and organisational variables. European Journal of Work and Organizational Psychology. 11(2): 219-241.

Shadur, M.A., Kienzle, R. \& Rodwell, J.J. (1999). The Relationship between Organizational Climate and Employee Perceptions of Involvement: The Importance of Support. Group \& Organization Management. 24(4): 479-503.

Shumaker, S.A. \& Brownell, A. (1984). Toward a Theory of Social Support: Closing Conceptual Gaps. Journal of Social Issues. 40(4): 11-36.

Stanton, P., Young, S., Bartram, T. \& Leggat, S.G. (2010). Singing the same song: translating HRM messages across management hierarchies in Australian hospitals. International Journal of Human Resource Management. 21(4): 567-581.

Thornhill, A. \& Saunders, M.N.K. (1998). What if line managers don't realize they're responsible for HR? Lessons from an organization experiencing rapid change. Personnel Review. 27(6): 460-476.

Vallerand, R.J. \& Ratelle, C.F. (2004). Intrinsic and extrinsic motivation: A hierarchical model. In Deci, E.L. \& Ryan, R.M. (Eds.). Handbook of self-determination research. Suffolk: University of Rochester Press, 37-63.

Vandenabeele, W. (2008) Toward a public administration theory of public service motivation. [doctoral thesis] KU Leuven.

Vandenabeele, W. (2009). The mediating effect of job satisfaction and organizational commitment on self-reported performance: more robust evidence of the PSM-performance relationship. International Review of Administrative Sciences. 75(1): 11-34.

Van Wart, M., Hondeghem, A., Bouckaert, G. \& Ruebens, S. (2012). Administrative Leadership in the Context of Governance. Paper presented at the XVI Annual Conference of the International Research Society for Public Management (IRSPM). Rome, Italy. 11-13 April 2012. 
Vigoda-Gadot, E. \& Talmud, I. (2010). Organizational Politics and Job Outcomes: The Moderating Effect of Trust and Social Support. Journal of Applied Social Psychology. 40(11): 2829-2861.

Watson, S., Maxwell, G.A. \& Farquharson, L. (2007). Line managers' views on adopting human resource roles: the case of Hilton (UK) hotels. Employee Relations. 29(1): 30-49.

Wayne, S.J., Shore, L.M. \& Liden, R.C. (1997). Perceived Organizational Support and Leader-Member Exchange: A Social Exchange Perspective. Academy of Management Journal. 40(1): 82-111.

Whittaker, S. \& Marchington, M. (2003) Devolving HR responsibility to the line: Threat, opportunity or partnership? Employee Relations. 25 (3): 245-261.

Wright, P.M. \& Nishii, L.H. (2013). Strategic HRM and Organizational Behavior: Integrating Multiple Levels of Analysis. In: Guest, D.E., Paauwe, J. \& Wright, P. (eds.). HRM and performance: Achievements and challenges. Chichester, UK: John Wiley \& Sons Ltd. pp. 79-96.

Wynen, J., Op de Beeck, S. \& Ruebens, S. (2015). The Nexus Between Gender and Perceived Career Opportunities: Evidence From the U.S. Federal Government. Public Personnel Management. Published online before print May 28, 2015.

Zhou, J. \& George, J.M. (2001). When Job Dissatisfaction Leads to Creativity: Encouraging the Expression of Voice. The Academy of Management Journal. 44(4): 682-696. 


\section{TABLES}

Table 1: Descriptive statistics

\begin{tabular}{|c|c|c|c|c|c|c|c|}
\hline \multirow[b]{2}{*}{ Variable } & \multicolumn{2}{|c|}{ Total sample $(\mathrm{N}=1,222)$} & \multicolumn{2}{|c|}{ FLM sample $(\mathrm{N}=850)$} & \multicolumn{2}{|c|}{ MM sample $(\mathrm{N}=372)$} & \multirow{2}{*}{$\begin{array}{r}\text { Significant } \\
\text { difference }\end{array}$} \\
\hline & Mean & SD & Mean & SD & Mean & SD & \\
\hline $\begin{array}{l}\text { HRM implementation } \\
\text { effectiveness }\end{array}$ & 3.517185 & 6577518 & 3.476863 & .6789605 & 3.609319 & .5972356 & $* * *$ \\
\hline \multicolumn{8}{|l|}{ Organisational variables } \\
\hline Organisational support & 2.415712 & .7686759 & 2.4 & .7681836 & 2.451613 & .7696291 & - \\
\hline Red tape & 6.762684 & 2.059154 & 6.783529 & 2.072357 & 6.715054 & 2.030625 & - \\
\hline Personnel red tape & 4.401309 & .5789637 & 4.400706 & .5878627 & 4.402688 & .5588719 & - \\
\hline \multicolumn{8}{|l|}{ Individual variables } \\
\hline Autonomous motivation & 4.361702 & 6.547385 & 4.097647 & 6.643443 & 4.965054 & 6.289628 & $* *$ \\
\hline Capacity & 3.149209 & .9702157 & 3.174902 & .9764925 & 3.090502 & .9544238 & - \\
\hline \multicolumn{8}{|l|}{ Interpersonal variables } \\
\hline HR support & 3.005237 & .8589494 & 2.968941 & .8551514 & 3.088172 & .8629979 & $* *$ \\
\hline Supervisor support & 3.151277 & 1.001707 & 3.154353 & 1.001288 & 3.144086 & 1.003977 & - \\
\hline Co-worker support & 3.127332 & .8502362 & 3.140706 & .8515015 & 3.096774 & .8476957 & - \\
\hline \multicolumn{8}{|l|}{ Control variables } \\
\hline Gender & .3559738 & .4790034 & .3976471 & 4896999 & .2607527 & .4396365 & $* * *$ \\
\hline Age & 50.69149 & 8.378275 & 49.36941 & 8.340233 & 53.71237 & 7.660629 & $* * *$ \\
\hline Age squared & 2639.765 & 808.4775 & 2506.816 & 793.5544 & 2943.546 & 759.6578 & $* * *$ \\
\hline Length of service & 21.89607 & 11.10628 & 20.29647 & 10.70095 & 25.55108 & 11.16478 & $* * *$ \\
\hline $\begin{array}{l}\text { Years of supervisory } \\
\text { experience }\end{array}$ & 14.31424 & 9.240855 & 12.14 & 8.442722 & 19.28226 & 9.074321 & $* * *$ \\
\hline Span of control & 11.75777 & 8.532076 & 9.195294 & 6.03031 & 17.6129 & 10.34138 & $* * *$ \\
\hline Local office & 1.843699 & .3632893 & 1.845882 & .3612741 & 1.83871 & .3682939 & - \\
\hline Organisation & 2.211129 & .408277 & 2.194118 & .3957528 & 2.25 & .4335959 & $* *$ \\
\hline Middle manager position & .304419 & .4603493 & - & - & - & - & - \\
\hline
\end{tabular}

Note: Depending on the data, specific statistical tests ( $t$-test, ANOVA) have been applied to test the significance between the two groups.

Significance levels: $* * * p<0.01, * * p<0.05, * p<0.10$ 
Table 2: OLS regression results

\begin{tabular}{|c|c|c|c|}
\hline Variables & $\begin{array}{c}\text { (A) } \\
\text { FLM }\end{array}$ & $\begin{array}{l}\text { (B) } \\
\text { MM }\end{array}$ & $\begin{array}{r}\text { Significant } \\
\text { difference }\end{array}$ \\
\hline \multicolumn{4}{|l|}{ Organisational variables } \\
\hline Organisational support & $\begin{array}{c}0.0858 * * \\
(0.0351)\end{array}$ & $\begin{array}{c}0.131 * * * \\
(0.0457)\end{array}$ & - \\
\hline Red tape & $\begin{array}{l}-0.0186 \\
(0.0120)\end{array}$ & $\begin{array}{r}-0.00946 \\
(0.0154)\end{array}$ & - \\
\hline Personnel red tape & $\begin{array}{c}0.0547 \\
(0.0384)\end{array}$ & $\begin{array}{c}-0.103^{* *} \\
(0.0520)\end{array}$ & $* *$ \\
\hline \multicolumn{4}{|l|}{ Individual variables } \\
\hline Autonomous motivation & $\begin{array}{c}0.0280 * * * \\
(0.00345)\end{array}$ & $\begin{array}{c}0.0385^{* * * *} \\
(0.00457)\end{array}$ & $*$ \\
\hline Capacity (-) & $\begin{array}{l}-0.0309 \\
(0.0250)\end{array}$ & $\begin{array}{l}0.00983 \\
(0.0325)\end{array}$ & - \\
\hline \multicolumn{4}{|l|}{ Interpersonal variables } \\
\hline HR support & $\begin{array}{c}-0.000845 \\
(0.0322)\end{array}$ & $\begin{array}{c}0.0102 \\
(0.0387)\end{array}$ & - \\
\hline Supervisor support & $\begin{array}{c}0.0337 \\
(0.0250)\end{array}$ & $\begin{array}{l}-0.0417 \\
(0.0318)\end{array}$ & $*$ \\
\hline Co-worker support & $\begin{array}{c}0.0915^{* * * *} \\
(0.0281)\end{array}$ & $\begin{array}{c}0.151 * * * \\
(0.0376)\end{array}$ & - \\
\hline \multicolumn{4}{|l|}{ Control variables } \\
\hline Gender & $\begin{array}{l}-0.0189 \\
(0.0473)\end{array}$ & $\begin{array}{c}0.0535 \\
(0.0667)\end{array}$ & - \\
\hline Age & $\begin{array}{c}0.0663 * * \\
(0.0271)\end{array}$ & $\begin{array}{l}-0.0432 \\
(0.0376)\end{array}$ & $* *$ \\
\hline Age squared & $\begin{array}{c}-0.000728 * * \\
(0.000285)\end{array}$ & $\begin{array}{c}0.000305 \\
(0.000378)\end{array}$ & $* *$ \\
\hline Length of service & $\begin{array}{c}0.00103 \\
(0.00272)\end{array}$ & $\begin{array}{c}0.00867 * * * \\
(0.00316)\end{array}$ & $* *$ \\
\hline Years of supervisory experience & $\begin{array}{c}0.00113 \\
(0.00336)\end{array}$ & $\begin{array}{c}0.00899 * * \\
(0.00399)\end{array}$ & - \\
\hline Span of control & $\begin{array}{c}0.00238 \\
(0.00378)\end{array}$ & $\begin{array}{c}0.00236 \\
(0.00289)\end{array}$ & - \\
\hline Local office & $\begin{array}{c}0.105^{*} \\
(0.0625)\end{array}$ & $\begin{array}{l}-0.0839 \\
(0.0778)\end{array}$ & $* *$ \\
\hline Organisation & $\begin{array}{c}0.0760 \\
(0.0621)\end{array}$ & $\begin{array}{l}-0.0365 \\
(0.0757)\end{array}$ & - \\
\hline Constant & $\begin{array}{c}0.889 \\
(0.699)\end{array}$ & $\begin{array}{c}4.421 * * * \\
(1.019)\end{array}$ & \\
\hline Observations & 850 & 372 & \\
\hline Adjusted R-squared & 0.163 & 0.280 & \\
\hline
\end{tabular}

Robust standard errors in parentheses

$* * * p<0.01, * * p<0.05, * p<0.1$ 


\section{FIGURES}

Figure 1: Effect of age on line managers' HRM implementation effectiveness

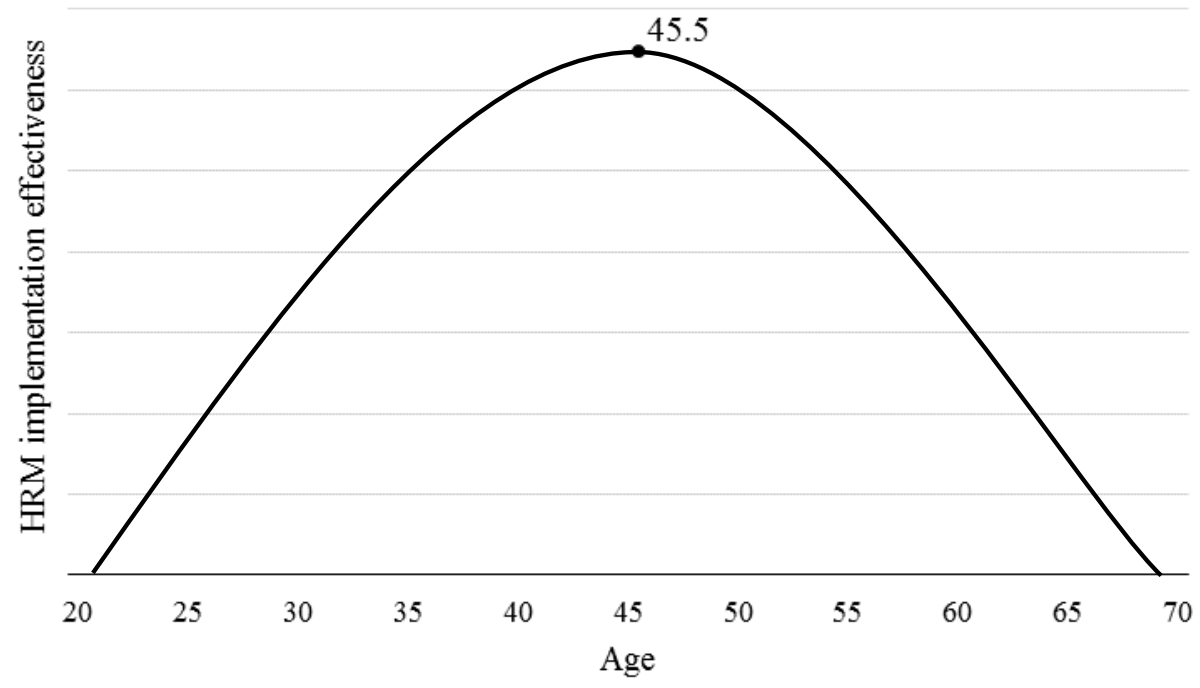




\section{APPENDIX}

\section{Final concepts and measures}

\begin{tabular}{|c|c|c|c|c|}
\hline & CONCEPT & OPERATIONALISATION & QUESTION / ITEMS & SCALE \\
\hline 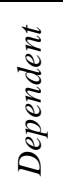 & $\begin{array}{l}\text { Line managers' perceived } \\
\text { HRM implementation } \\
\text { effectiveness (Cronbach's } \\
\text { alpha: } 0.7721 \text { ) }\end{array}$ & $\begin{array}{l}\text { Self-reported performance } \\
\text { (Vandenabeele, 2009) }\end{array}$ & $\begin{array}{l}\text { - In my opinion, I contribute to the success of the HR policy in my organisation. } \\
\text { - I think I am performing well in executing my HRM responsibilities. } \\
\text { - With regards to my HR tasks, I think I am a good line manager. }\end{array}$ & $\begin{array}{l}1 \text { totally } \\
\text { disagree }-5 \\
\text { totally agree }\end{array}$ \\
\hline \multirow{3}{*}{ 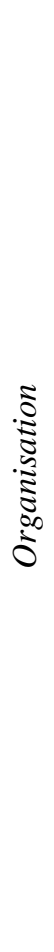 } & $\begin{array}{l}\text { Organisational support } \\
\text { (Cronbach's alpha:0.7490) }\end{array}$ & $\begin{array}{l}\text { Perceived organisational } \\
\text { support (Zhou \& George, 2001) }\end{array}$ & $\begin{array}{l}\text { - The execution of HR tasks by line managers is encouraged in my organisation. } \\
\text { - The role of line managers in executing HR tasks is respected by the leadership in my } \\
\text { organisation. } \\
\text { - The reward system in my organisation encourages line managers to execute their HR } \\
\text { tasks. } \\
\text { - The line managers who perform well in the execution of their HR tasks are publicly } \\
\text { recognised by the organisation. }\end{array}$ & $\begin{array}{l}1 \text { totally } \\
\text { disagree }-5 \\
\text { totally agree }\end{array}$ \\
\hline & Red tape & Red tape (Rainey et al., 1995) & $\begin{array}{l}\text { If red tape is defined as 'burdensome administrative rules and procedures that have } \\
\text { negative effects on the organisation's effectiveness', how would you assess the level of } \\
\text { red tape in your organisation? }\end{array}$ & $\begin{array}{l}0 \text { almost no } \\
\text { red tape }-10 \\
\text { great deal of } \\
\text { red tape }\end{array}$ \\
\hline & $\begin{array}{l}\text { Personnel red tape } \\
\text { (Cronbach's alpha: 0.7294) }\end{array}$ & $\begin{array}{l}\text { Personnel red tape (Rainey et } \\
\text { al., 1995) }\end{array}$ & $\begin{array}{l}\text { - Even when an employee performs poorly, formal rules make it hard to remove him or } \\
\text { her from the organisation. } \\
\text { - The rules governing promotion make it hard for a good employee to move up faster } \\
\text { than a poor one. } \\
\text { - Due to formal rules, pay raises for employees are based primarily on seniority instead } \\
\text { of performance. } \\
\text { - The formal pay structures and rules make it hard to reward a good employee with } \\
\text { higher pay. } \\
\text { - The personnel rules and procedures that govern my organisation make it easy for } \\
\text { superiors to reward subordinates for good performance. (R) }\end{array}$ & $\begin{array}{l}1 \text { totally } \\
\text { disagree }-5 \\
\text { totally agree }\end{array}$ \\
\hline
\end{tabular}




\begin{tabular}{|c|c|c|c|c|}
\hline \multirow[b]{2}{*}{ 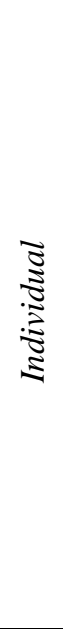 } & $\begin{array}{l}\text { Capacity } \\
\text { (Cronbach's alpha: 0.8245) }\end{array}$ & Role overload (Reilly, 1982) & $\begin{array}{l}\text { - I have to perform HR tasks which I don't really have the time for. (R) } \\
\text { - I feel I have to perform HR tasks hastily and maybe less carefully in order to get } \\
\text { everything done. (R) } \\
\text { - My HR tasks lead to a workload that is too heavy. (R) }\end{array}$ & $\begin{array}{l}1 \text { totally } \\
\text { disagree }-5 \\
\text { totally agree }\end{array}$ \\
\hline & Autonomous motivation & $\begin{array}{l}\text { Relative autonomy index } \\
\text { (Vandenabeele, 2008; Coursey } \\
\text { \& Vandenabeele, 2012) }\end{array}$ & $\begin{array}{l}\text { I try to do my best in executing my HR tasks, because... } \\
\text { - Otherwise, I might create problems for myself (External regulation) } \\
\text { - Otherwise, I risk receiving a negative staff appraisal (External regulation) } \\
\text { - Otherwise, I will feel bad about it (Introjected regulation) } \\
\text { - Otherwise, I will feel guilty about it (Introjected regulation) } \\
\text { - I would like to be a good supervisor (Identified regulation) } \\
\text { - I consider it my duty (Identified regulation) } \\
\text { - I think my it is interesting (Intrinsic regulation) } \\
\text { - I enjoy it (Intrinsic regulation) }\end{array}$ & $\begin{array}{l}1 \text { totally } \\
\text { disagree }-5 \\
\text { totally agree } \\
\text { (combined } \\
\text { into an } \\
\text { additive } \\
\text { weighted } \\
\text { score) }\end{array}$ \\
\hline \multirow{2}{*}{$\begin{array}{l}\bar{\Xi} \\
\vdots \\
\vdots \\
\vdots \\
\vdots \\
\vdots \\
\vdots\end{array}$} & $\begin{array}{l}\text { HR support } \\
\text { (Cronbach's alpha: 0.9113) }\end{array}$ & $\begin{array}{l}\text { Perceived support scale } \\
\text { developed by Gilbert et al. } \\
\text { (2011) based on support scales } \\
\text { by Perry and Kulik (2008) and } \\
\text { House (1981) }\end{array}$ & $\begin{array}{l}\text { - The HR department/HR professionals provide(s) the necessary resources to help me } \\
\text { perform my HR tasks. } \\
\text { - The HR department/HR professionals support(s) me in executing my HR tasks. } \\
\text { - The HR department/HR professionals is/are always ready to help me with my HR } \\
\text { tasks. } \\
\text { - If necessary, I can count on the expertise of the HR department/HR professionals to } \\
\text { execute my HR tasks. } \\
\text { - If I encounter a problem in the execution of my HR tasks, I can always count on the } \\
\text { HR department/HR professionals. }\end{array}$ & $\begin{array}{l}1 \text { totally } \\
\text { disagree }-5 \\
\text { totally agree }\end{array}$ \\
\hline & $\begin{array}{l}\text { Supervisor support } \\
\text { (Cronbach's alpha: 0.9428) }\end{array}$ & $\begin{array}{l}\text { Idem HR support, adapted for } \\
\text { supervisor }\end{array}$ & $\begin{array}{l}\text { - My supervisor provides the necessary resources to help me perform my HR tasks. } \\
\text { - My supervisor supports me in executing my HR tasks. } \\
\text { - My supervisor is always ready to help me with my HR tasks. } \\
\text { - If necessary, I can count on the expertise of my supervisor to execute my HR tasks. } \\
\text { - If I encounter a problem in the execution of my HR tasks, I can always count on my } \\
\text { supervisor. }\end{array}$ & $\begin{array}{l}1 \text { totally } \\
\text { disagree }-5 \\
\text { totally agree }\end{array}$ \\
\hline
\end{tabular}




\begin{tabular}{|c|c|c|c|c|}
\hline & $\begin{array}{l}\text { Co-worker support } \\
\text { (Cronbach's alpha: 0.9142) }\end{array}$ & $\begin{array}{l}\text { Idem HR support, adapted for } \\
\text { co-worker }\end{array}$ & $\begin{array}{l}\text { - My colleagues provide the necessary resources to help me perform my HR tasks. } \\
\text { - My colleagues support me in executing my HR tasks. } \\
\text { - My colleagues are always ready to help me with my HR tasks. } \\
\text { - If necessary, I can count on the expertise of my colleagues to execute my HR tasks. } \\
\text { - If I encounter a problem in the execution of my HR tasks, I can always count on my } \\
\text { colleagues. }\end{array}$ & $\begin{array}{l}1 \text { totally } \\
\text { disagree - } 5 \\
\text { totally agree }\end{array}$ \\
\hline \multirow{7}{*}{ 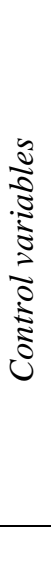 } & Gender & - & What is your gender? & Dummy \\
\hline & Age & - & Which year were you born in? & $\begin{array}{l}\text { Continuous } \\
(1940-2000)\end{array}$ \\
\hline & Length of service & - & What is your length of service in the current organisation? & $\begin{array}{l}\text { Continuous } \\
(<1->45 \mathrm{yrs})\end{array}$ \\
\hline & Supervisory experience & - & How many years have you been working in a supervisory position? & $\begin{array}{l}\text { Continuous } \\
(<1->45 \text { yrs })\end{array}$ \\
\hline & Span of control & - & How many people work under your direct supervision, i.e. size of your team? & $\begin{array}{l}\text { Continuous ( } 0 \\
-30 \text { or more) }\end{array}$ \\
\hline & $\begin{array}{l}\text { Central versus local office } \\
\text { position }\end{array}$ & - & Do you work in a central office or in a local office? & Dummy \\
\hline & Organisation & - & Which organisation do you currently work in? & Dummy \\
\hline
\end{tabular}


Correlation matrix

\begin{tabular}{|c|c|c|c|c|c|c|c|c|c|c|c|c|c|c|c|c|c|c|}
\hline Variable & & $(1)$ & $(2)$ & (3) & $(4)$ & (5) & $(6)$ & $(7)$ & $(8)$ & (9) & (10) & (11) & (12) & (13) & (14) & (15) & (16) & (17) \\
\hline $\mathrm{y}$ & (1) & 1 & & & & & & & & & & & & & & & & \\
\hline $\begin{array}{l}\text { Organisational } \\
\text { support }\end{array}$ & (2) & $0.18 * * *$ & 1 & & & & & & & & & & & & & & & \\
\hline Red tape & (3) & $-0.16 * * *$ & $-0.33 * * *$ & 1 & & & & & & & & & & & & & & \\
\hline $\begin{array}{l}\text { Personnel red } \\
\text { tape }\end{array}$ & (4) & -0.01 & $-0.23 * * *$ & $0.14 * * *$ & 1 & & & & & & & & & & & & & \\
\hline $\begin{array}{l}\text { Autonomous } \\
\text { motivation }\end{array}$ & (5) & $0.33 * * *$ & -0.02 & $-0.11 * * *$ & 0.05 & 1 & & & & & & & & & & & & \\
\hline Capacity & (6) & $-0.17 * * *$ & $-0.17 * * *$ & $0.34 * * *$ & $0.05 *$ & $-0.26 * * *$ & 1 & & & & & & & & & & & \\
\hline HR support & (7) & $0.17 * * *$ & $0.48 * * *$ & $-0.35 * * *$ & $-0.07 * *$ & $0.07 * *$ & $-0.30 * * *$ & 1 & & & & & & & & & & \\
\hline $\begin{array}{l}\text { Supervisor } \\
\text { support }\end{array}$ & (8) & $0.15 * * *$ & $0.39 * * *$ & $-0.19 * * *$ & $-0.07 * *$ & $0.09 * * *$ & $-0.18 * * *$ & $0.37 * * *$ & 1 & & & & & & & & & \\
\hline $\begin{array}{l}\text { Co-worker } \\
\text { support }\end{array}$ & (9) & $0.20 * * *$ & $0.25 * * *$ & $-0.11 * * *$ & -0.04 & $0.08 * * *$ & $-0.12 * * *$ & $0.33 * * *$ & $0.33 * * *$ & 1 & & & & & & & & \\
\hline Gender & (10) & 0.06 & -0.01 & $-0.06 * *$ & -0.01 & $0.14 * * *$ & $-0.11 * * *$ & 0.04 & 0.01 & $0.08 * * *$ & 1 & & & & & & & \\
\hline Age squared & (12) & -0.01 & $0.08 * * *$ & -0.05 & 0.01 & $-0.08 * * *$ & -0.03 & 0.01 & 0.00 & $-0.08 * * *$ & $-0.27 * * *$ & $0.99 * * *$ & 1 & & & & & \\
\hline $\begin{array}{l}\text { Length of } \\
\text { service }\end{array}$ & (13) & 0.04 & $0.08^{* * *}$ & -0.04 & 0.02 & $-0.08 * * *$ & -0.02 & 0.02 & -0.02 & $-0.06 * *$ & $-0.14 * * *$ & $0.65 * * *$ & $0.65 * * *$ & 1 & & & & \\
\hline $\begin{array}{l}\text { Years of } \\
\text { supervisory } \\
\text { experience }\end{array}$ & (14) & 0.05 & 0.05 & -0.01 & $0.07 * *$ & -0.02 & $-0.06^{*}$ & $0.05 *$ & -0.03 & $-0.08 * * *$ & $-0.21 * * *$ & $0.63 * * *$ & $0.64 * * *$ & $0.54 * * *$ & 1 & & & \\
\hline $\begin{array}{l}\text { Span of } \\
\text { control }\end{array}$ & (15) & $0.10 * * *$ & $0.13 * * *$ & -0.10 & $0.05^{*}$ & 0.04 & 0.03 & $0.14 * * *$ & 0.03 & 0.01 & $-0.11 * * *$ & $0.19 * * *$ & $0.19 * * *$ & $0.12 * * *$ & $0.25 * * *$ & 1 & & \\
\hline Local office & (16) & 0.22 & -0.02 & $0.08 * * *$ & $0.12 * * *$ & $-0.06^{* *}$ & 0.04 & -0.03 & -0.02 & $0.10 * * *$ & 0.04 & 0.032 & 0.03 & $0.07 * *$ & $0.09 * * *$ & 0.04 & 1 & \\
\hline Organisatie & (17) & $0.14 * * *$ & $0.30 * * *$ & $-0.26 * * *$ & -0.03 & $0.11 * * *$ & $-0.19 * * *$ & $0.27 * * *$ & $0.22 * * *$ & $0.07 * *$ & $0.14 * * *$ & -0.015 & -0.01 & $0.06 * *$ & $0.09 * * *$ & $0.25 * * *$ & $-0.12 * * *$ & 1 \\
\hline
\end{tabular}

